\title{
Bryoflora of the municipalities of Soure and Cachoeira do Arari, on Marajó Island, in the state of Pará, Brazil ${ }^{1}$
}

Eliete da Silva Brito ${ }^{2,3}$ and Anna Luiza Ilkiu-Borges ${ }^{2}$

Submitted: 6 February, 2012. Accepted: 9 November, 2012

\begin{abstract}
This study aims to investigate the richness and ecological aspects (ecosystem and substrate) of mosses and liverworts at two municipalities on Marajó Island, in the state of Pará, Brazil. The study area $\left(6615 \mathrm{~km}^{2}\right)$ encompasses the municipalities of Soure and Cachoeira do Arari. Bryophytes were collected from the 10th to the 16th of January, 2007, during random visits along existing trails or during the forging of new trails, from all possible types of vegetation, regardless of the type of substrate. The ecosystems visited in the study area were capoeira (secondary vegetation, growing on land that has been burned or cleared), teso (vegetation growing on areas of land at an elevation slightly higher than the water line during flood season), floodplain forest, mangrove forests, cerrado (savanna) and natural grasslands (pure and mixed). In total, 11 families, 30 genera, and 67 species were recorded, of which 39 represented new records for the island. Cololejeunea panamensis G. Dauphin \& Pocs represented a new record for South America; Microlejeunea subulistipa Steph. represented a new record for the northern region of Brazil, and Cololejeunea verwimpii Tixier and Mastigolejeunea innovans (Spruce) Steph. represented new records for the state of Pará.
\end{abstract}

Key words: Bryophyta, Marchantiophyta, Bryophytes, Amazon, neotropics

\section{Introduction}

Insular environments can contain a subset of continental flora (Tan \& Pócs 2000). Therefore, floristic studies on islands are important to determine how and which species are distributed in these locations. Yano \& Peralta (2008) analyzed studies of bryophytes on islands in the state of São Paulo and noted that the composition of species found on the islands does not seem to differ from that of those found on the continent. However, the authors stress the importance of conducting taxonomic and ecological studies to understand the population dynamics of bryophytes in island environments.

Marajó Island is a continental, fluvial-marine island of approximately $48,000 \mathrm{~km}^{2}$ located at the mouth of the Amazon River in the state of Pará, and is geopolitically subdivided into 12 municipalities (Cruz 1987): Afuá, Anajás, Breves, Cachoeira do Arari, Chaves, Curralinho, Muaná, Ponta de Pedras, Salvaterra, Santa Cruz do Arari, São Sebastião da Boa Vista and Soure.

On Marajó Island, exploitative activities such as mining and overgrazing are quite common (Ferreira et al. 2001). The island's vegetation is used for various purposes, such as those of the construction and furniture industries (Amaral et al. 2007). However, overexploitation results in habitat degradation and the suppression of vegetation at levels that threaten biodiversity in the Amazon (MMA 2004). For bryophytes, one of the predicted changes is the loss of specific groups, such as epiphytic bryophytes (Gradstein 1992). The recommendations made by the Conservation Action Plan for Bryophytes (Plano de Ação para Conservação das Briófitas) include increasing inventories to determine the richness and types of habitats in various tropical regions (Hallingbäck \& Hodgetts 2000).

The first studies on the bryophytes of Marajó Island were conducted in the 1990s and combined records collected in four municipalities: Salvaterra, Afuá, Anajás and Chaves. Most of those studies, however, dealt only with mosses, with the exception of that conducted by Lisboa et al. (1993) in Salvaterra, which included liverwort records (related to a total of 12 species, belonging to five families). Lisboa \& Maciel (1994) studied the bryophytes in the municipality of Afuá, where 31 species of mosses (of 15 families) were reported. In the city of Chaves, Lisboa et al. (1998) identified 18 species (of nine families), and in Anajás, Lisboa et al. (1999) cataloged 34 mosses (of 17 families).

\footnotetext{
${ }^{1}$ Based on the Master's dissertation of the first Author

${ }^{2}$ Museu Paraense Emílio Goeldi, Belém, PA, Brazil

${ }^{3}$ Author for correspondence: eliete_briofita@hotmail.com
} 
Recent studies have included mosses as well as liverworts. L. P. Macedo conducted a study in 2009 involving bryophytes found on palm trees in the municipalities of Soure and Cachoeira do Arari (unpublished data). That study identified 21 species (13 mosses and eight liverworts). In addition, D. N. Fagundes and E. T. Garcia, also in 2009, identified 26 species (15 mosses and 11 liverworts) from the Bacurizal Reserve in the municipality of Salvaterra (Fagundes \& Garcia, personal communication).

Marajó Island bryophytes are known on the basis of studies of the bryoflora from six of the 12 municipalities on the island, and liverworts have been recorded in only half of the municipalities studied. Therefore, it appears that knowledge about Marajó bryoflora remains incipient, particularly as it regards liverworts. In addition, the ongoing deforestation resulting from ranching and mining in this region might have caused habitat loss and consequently the disappearance of species yet unknown, lending an urgent quality to the need for a survey of bryoflora in the region. The aim of this work is to investigate the richness and ecological aspects (ecosystem and substrate) of mosses and liverworts in selected municipalities on Marajó Island.

\section{Material and methods}

The study area $\left(6615 \mathrm{~km}^{2}\right)$ includes the municipalities of Soure and Cachoeira do Arari (Fig. 1). The region is classified as aving a humid, equatorial climate (Amaral et al. 2007; Cruz 1987). The vegetation comprises floodplain forests, grasslands, teso (vegetation growing on areas of land at an elevation slightly higher than the water line during flood season), mangrove forests and many areas of secondary vegetation (Capobianco et al. 2001). The altitude ranges from 4 to $20 \mathrm{~m}$ above sea level (Cruz 1987). Bryophytes were collected from the 10th to the 16th of January, 2007, during random visits along existing trails or during the forging new trails, from all possible types of vegetation, regardless of the type of substrate.

The environments visited in the study area (Tab. 1) were classified on the basis of Pires \& Prance (1985) and Amaral et al. (2007; 2008), being broadly characterized by the collectors as capoeira (secondary vegetation, or vegetation that grows on land previously burned or cleared), resulting from human activity, such as family agriculture, logging and artificial pastures; teso, an environment characterized by Desmoncus spp., Bactris maraja Mart., Euterpe oleracea Mart. and Guadua spp., in black soil; floodplain forests, defined as ecosystems that border fast-moving rivers or muddy river basins; mangrove forests, composed of narrow strips of coastal vegetation and subject to flooding; (5) cerrado, or savanna, physiognomically similar to that found in central Brazil but with different soil and climate.

There are also natural grasslands, known as pure grasslands and mixed grasslands (6). In the pure grasslands on Marajó Island, the landscape matches the description of pure grassland savanna. In such grasslands, the herbaceous layer, which resembles a mosaic, forms copses or even forest islands dozens of hectares in size or interspersed with groups of palm trees. The soil is sandy-loamy and blackened, but there are large areas (patches) of white sand. However, in the mixed, or shrubby-arboreal, grasslands, the landscape features small copses and forest islands of varying size and shape; the environment contains many isolated trees or large groups of trees; and the soil is dark, being either sandy or a mixture of sandy and loamy.

The collection and preservation of samples followed the methodology described by Lisboa (1993). The species were identified on the basis of the bibliography cited here, such as Bischler et al. (1963), Buck (2003), Dauphin (2003), Florschütz (1964), Gradstein (1994), Gradstein \& Costa (2003), Gradstein \& Ilkiu-Borges (2009), Ilkiu-Borges \& Lisboa (2002a; 2004a; 2004b), Ireland \& Buck (1994), Lisboa (1993), Reese (1993), Reiner-Drehwald (1994; 2009), Schuster (1980), Tixier (1991), Van Slageren (1985) and Zartman \& Ilkiu-Borges (2007). The classification systems adopted were that of Crandall-Stotler et al. (2009) for Marchantiophyta and that of Goffinet et al. (2009) for Bryophyta. For each species, aspects of their ecology (ecosystem and substrate), material selected and worldwide distribution pattern were characterized as per Costa et al. (2007), Costa et al. (2010), Reiner-Drehwald (2009), Florschütz (1964), Gradstein (1994), Gradstein \& Costa (2003), Ireland \& Buck (1994), Pursell (2007), Reese (1993), Santos \& Costa (2010), Sharp et al. (1994), Tropicos (2011), Valente \& Pôrto (2006) and Yano $(2006 ; 2008)$.

The species were classified according to the substrate on which they were found (Robbins 1952). Species that occurred on living leaves were classified as epiphylls , and those collected from termites mounds (termitaria) were treated as a class apart, because they do not fit into any of the previously defined categories. The collected samples were preserved and deposited in the Emílio Goeldi Paraense Museum Herbarium, located in the city of Belém.

\section{Results and discussion}

In Soure and Cachoeira do Arari, we recorded 1275 occurrences of bryophytes across 67 species, 30 genera and 11 families (Tab. 1). We analyzed 617 samples containing bryophytes. However, only a representative sample of each species will be presented as the selected material.

Mosses were represented by 25 species in 13 genera and eight families, of which the two most representative were Fissidentaceae (seven species) and Calymperaceae (six species). These families are among the most common in tropical America (Gradstein et al. 2001). Fissidentaceae is found mainly in the tropical regions of the globe (Pursell 2007; Gradstein et al. 2001), and Calymperaceae is one of the richest and most abundant families in lowland forests of the neotropics (Gradstein et al. 2001). 

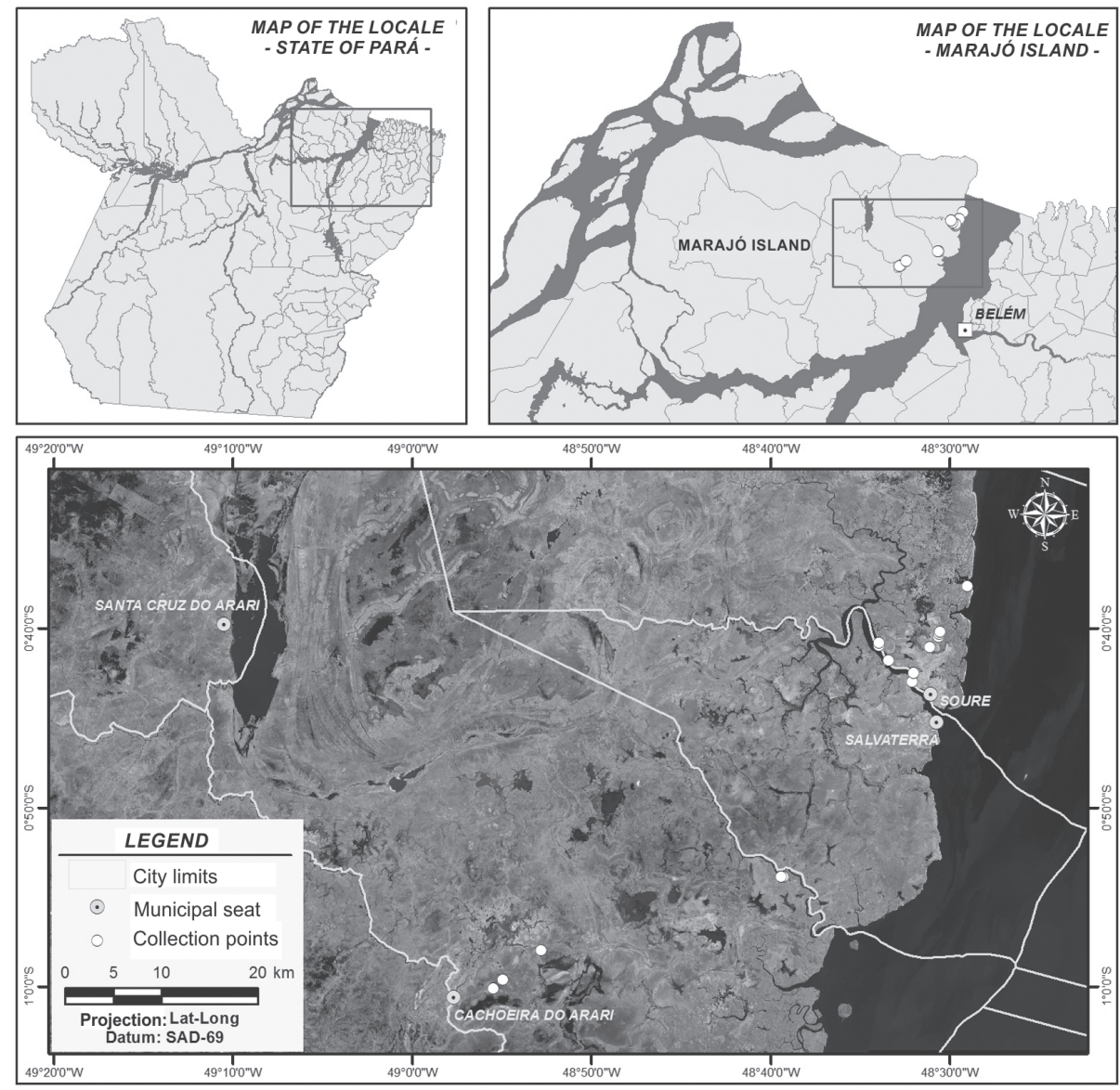

Figure 1. Map of Marajó Island, highlighting the municipal seats of Soure and Cachoeira do Arari, as well as the collection points.

Of the liverworts, we recorded 42 species in 17 genera and three families. This group had higher species richness (63\%) when compared with mosses (37\%). Among families of liverworts, as expected, Lejeuneaceae showed the highest richness (39 species, $93 \%$ of the diversity of the group in the area). The most representative genera also belonged to Lejeuneaceae, including Cheilolejeunea (Spruce) Schiffn. (seven species), as well as Cololejeunea (Spruce) Schiffn. and Lejeunea Lib. (five species each).

Of the species recorded, $6 \%$ represented new records: Cololejeunea verwimpii and Mastigolejeunea innovans, collected here for the first time in the state of Pará; $M i-$ crolejeunea subulistipa, a new record for northern Brazil; and Cololejeunea panamensis, a new record for South America and recorded here for the second time since the species was first described (Brito \& Ilkiu-Borges 2012). We also documented new records for six liverwort genera (Mastigolejeunea, Plagiochila, Prionolejeunea, Rectolejeunea, Stictolejeunea and Symbiezidium) and two moss genera (Entodontopsis and Pterogonidium).

Of the species recorded in Soure and Cachoeira do Arari, 94\% have a wide distribution in Brazil, occurring in three or more phytogeographic domains. As for worldwide distribution, the predominant distribution was neotropical
(60\%), followed by pantropical (24\%), and the tropics of Africa and the Americas (6\%), only $3 \%$ occurring in tropical and subtropical America. Only one species, Taxithelium planum, showed wide distribution. The species Trichosteleum papillosum has only been recorded in South America. Microlejeunea subulistipa and Archilejeunea crispistipula have restricted distribution in Brazil (Tab. 1). Similar results for the predominance of neotropical species distribution were found in several studies conducted in Brazil, such as that conducted by Costa \& Santos (2010) in the Atlantic Forest of Rio de Janeiro, as well as those conducted by Osakada \& Lisboa (2004), Alvarenga et al. $(2007,2008)$ and Tavares (2009) in the Amazon Rainforest within the state of Pará.

Among the species studied, Archilejeunea crispistipula and Microlejeunea acutifolia are exclusive to the Amazon phytogeographic domain and Microlejeunea subulistipa, previously found only in the Atlantic Forest, had expanded its distribution, with disjunct distributions in the Amazon and Atlantic Forest. Similar patterns were found by Santos \& Costa (2010) while studying the phytogeography of liverworts in the Atlantic Forest. It is believed that during the formation of the Atlantic Forest there were periods of contact with other vegetation formations, such as the Amazon and Andean Forests (Leitão-Filho 1987; Rizzini 1997). 


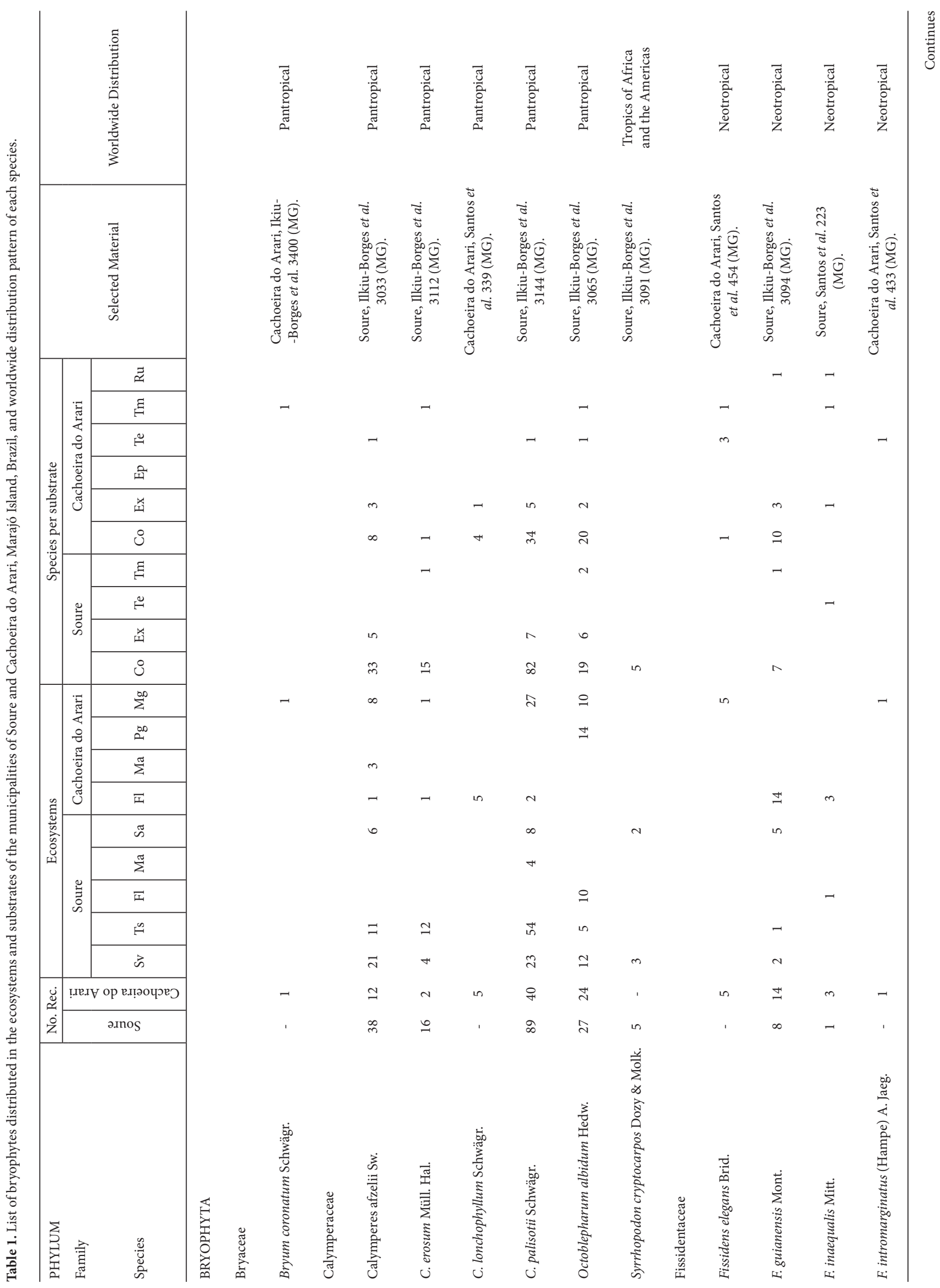


Eliete da Silva Brito and Anna Luiza Ilkiu-Borges

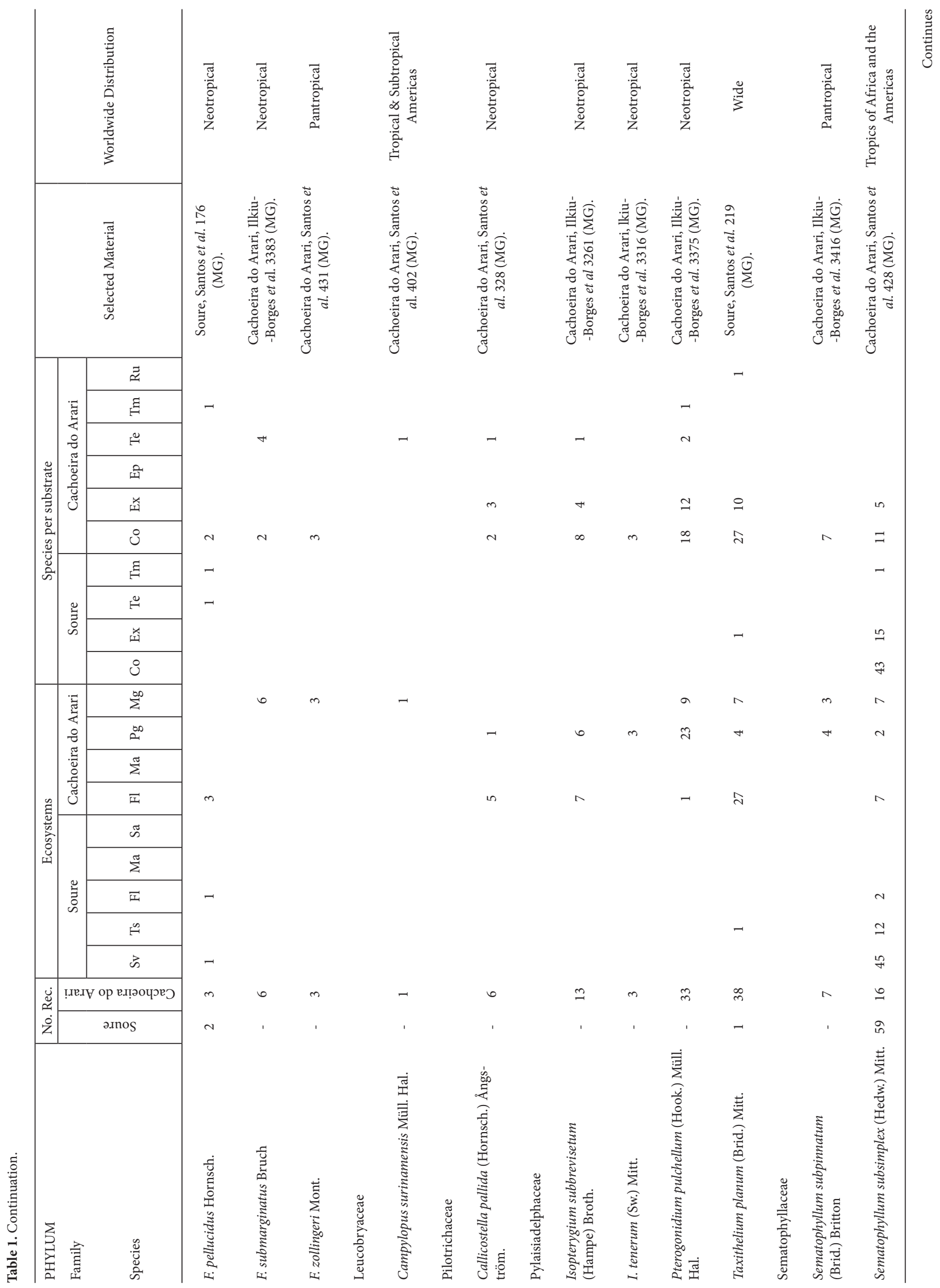


Bryoflora of the municipalities of Soure and Cachoeira do Arari, on Marajó Island, in the state of Pará, Brazil

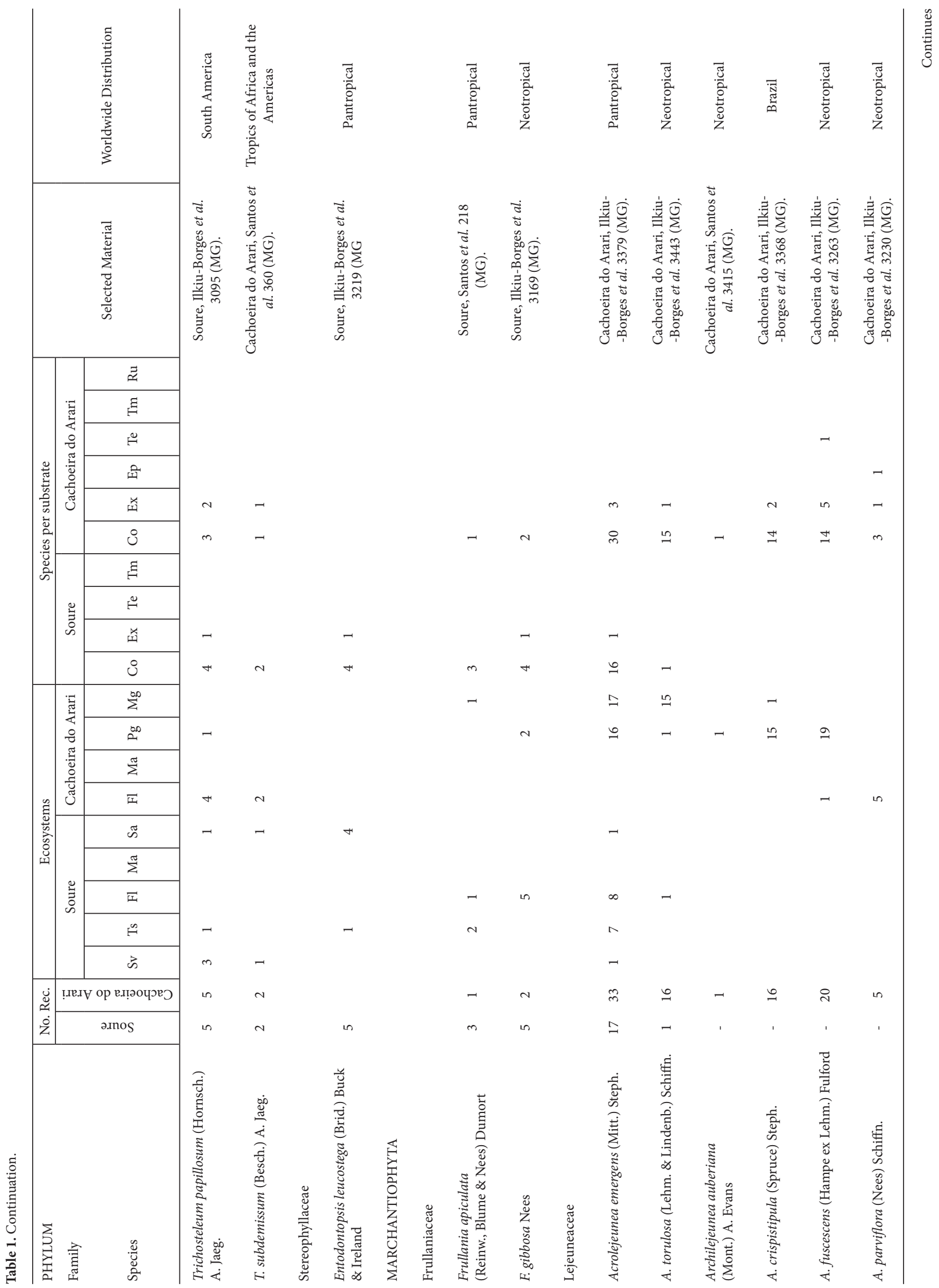


Eliete da Silva Brito and Anna Luiza Ilkiu-Borges

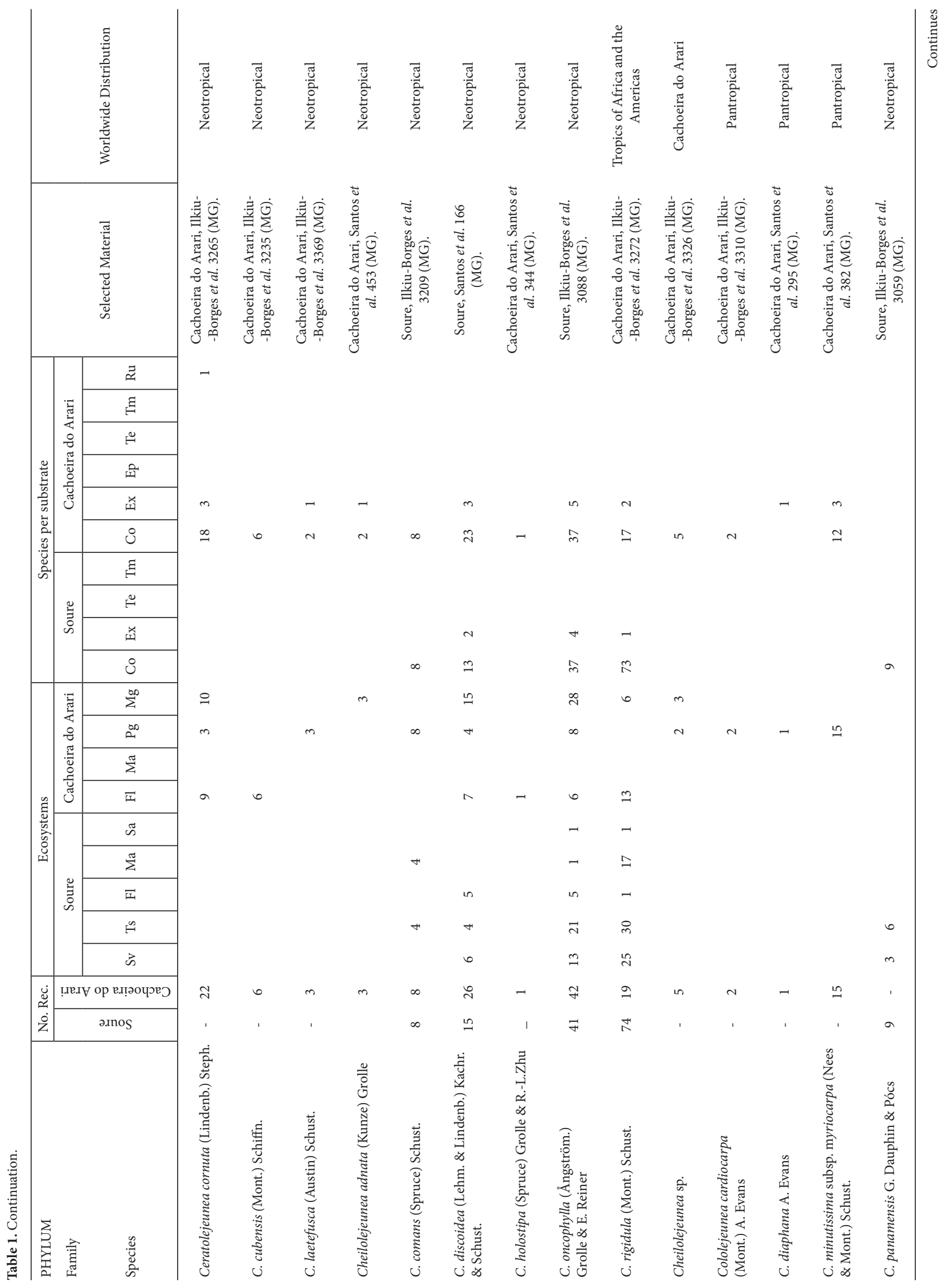


Bryoflora of the municipalities of Soure and Cachoeira do Arari, on Marajó Island, in the state of Pará, Brazil

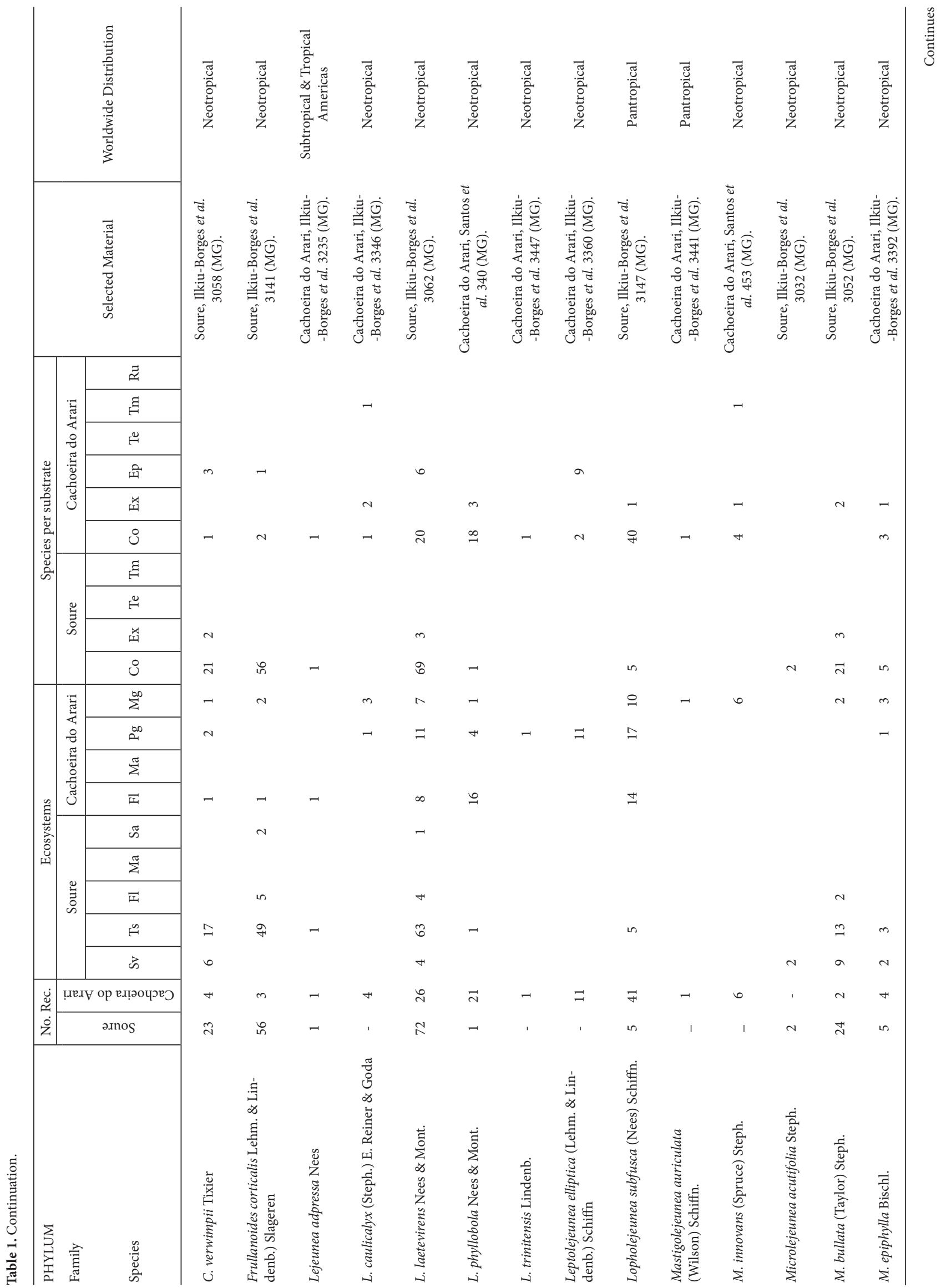


Eliete da Silva Brito and Anna Luiza Ilkiu-Borges

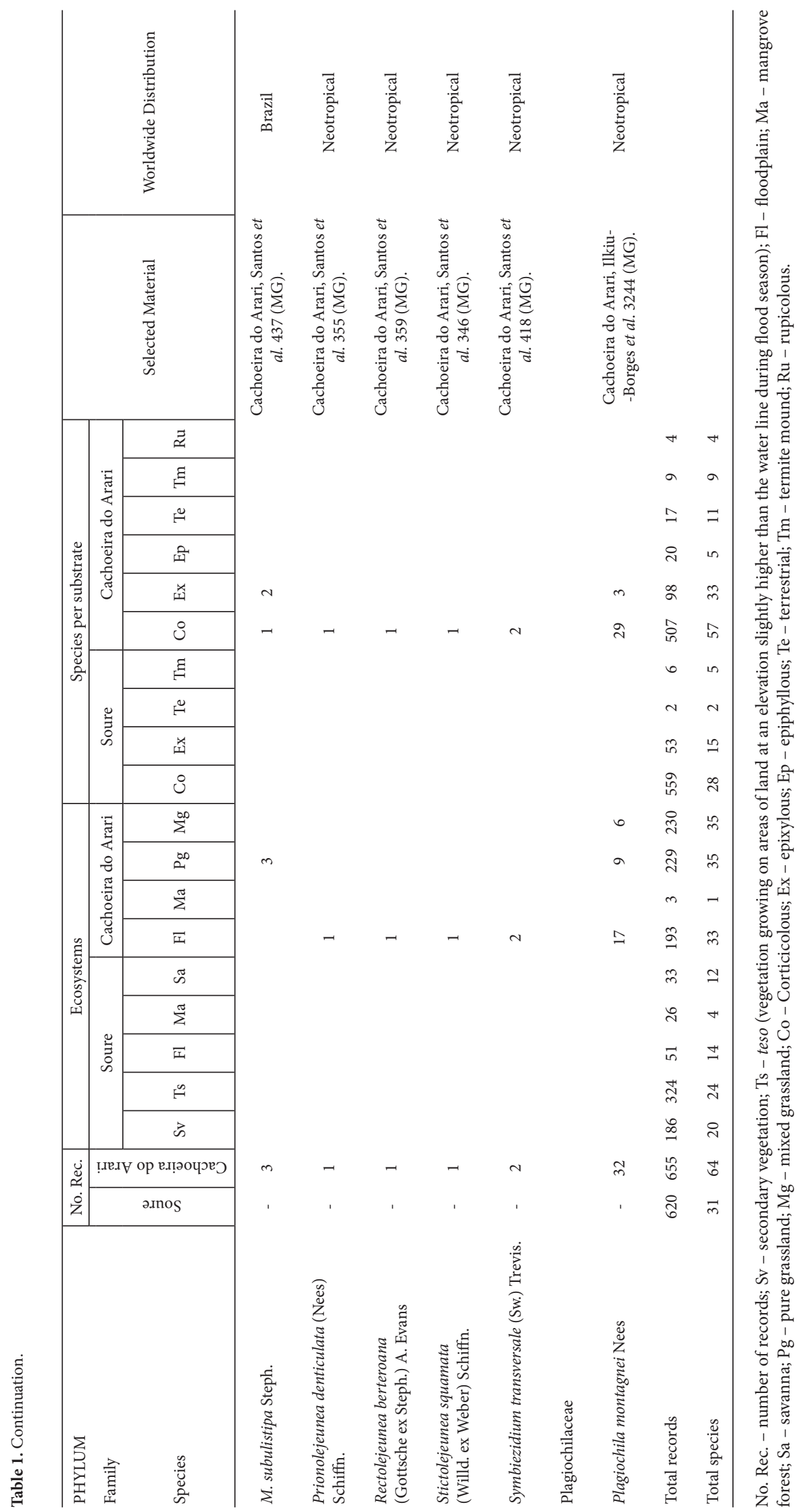


Studies on patterns of geographic distribution are mentioned by Fiaschi \& Pirani (2009), who state that those patterns, for vascular plants in Brazil, are generally in agreement with the main geomorphological domains and related types of vegetation. However, due to their forms of dispersion, bryophytes have a wider distribution than spermatophytes (Watson 1974; Tan \& Pócs 2000).

There was an observable difference in species richness between the ecosystems studied. In Soure, 31 species were recorded, including 13 belonging to the Bryophyta division and 18 belonging to Marchantiophyta. As shown in Tab. 1, the bryoflora in Cachoeira do Arari was richer in terms of species (63 species) when compared with Bryophyta (23 species) and Marchantiophyta (40 species). This result might not have been influenced by sampling difference, because the bryoflora present in Soure and Cachoeira do Arari was estimated on the basis of 620 and 655 samples, respectively. Regarding the groups studied in these municipalities, Soure produced the majority of Bryophyta records (258, compared with 243 in Cachoeira), while Cachoeira do Arari was predominant in Marchantiophyta (412 vs. 362), as can be seen in Fig. 2.

Fig. 3 illustrates the ratio between the most frequently occurring species, which represent $28 \%$ of species cited in this work. Some of them are among the most commonly cited in the literature concerned with the study of bryoflora in the Lower Amazon and the coast of Pará, such as: Sematophyllum subsimplex (Santos \& Lisboa 2003; 2008; Sousa \& Lisboa 2005; Moraes \& Lisboa 2006; Ilkiu-Borges et al. 2009), Octoblepharum albidum albidum (Moraes \& Lisboa 2009; Santos \& Lisboa 2003; 2008; Ilkiu-Borges et al. 2009), Taxithelium planum (Santos \& Lisboa 2003; Sousa \& Lisboa 2005), Calymperes palisotii (Lisboa et al 1998; Lisboa \& Tavares 2008; Santos \& Lisboa 2003; 2008; Ilkiu-Borges et al. 2009), Cheilolejeunea rigidula (Lisboa \& Tavares 2008), Archilejeunea fuscescens (Ilkiu-Borges \& Lisboa 2002a) and Ceratolejeunea cornuta (Ilkiu-Borges \& Lisboa 2002a). These species have a wide distribution pattern (Tab. 1), as well as broad ecological amplitude. Consequently, this result was expected, given that the vegetation of the region has been altered considerably.

Soure presented five types of ecosystems and Cachoeira do Arari presented four types (Tab. 1). A variation in species composition was recorded within these municipalities. In the first, $13 \%$ of the reported species were unique, compared with $57 \%$ in the second. These results reflect the difference in species richness and the predominance of mosses and liverworts found in each municipality, which is probably associated with microclimatic variations (mainly humidity) and abiotic variations in the various ecosystems studied. The majority of unique species were collected in Cachoeira do Arari, in the more forested grassland areas, and this might have influenced the richness as well as the quality of these species, i.e., favoring species with narrower ecological niches and therefore less tolerant to environmental changes.
Regarding the number of records in particular ecosystems, this followed the same pattern as species richness. Thus, the ecosystems in which the highest numbers of records were observed were mixed and pure grasslands (459), followed by teso (324), floodplain forest (244) and secondary vegetation (186). Regarding the number of species, the mixed and pure grasslands also predominated, with 35 species each, followed by floodplains (47 species), teso (24 species) and secondary vegetation (20 species).

Of the species recorded in this study, 18 (27\%) were observed only in the pure and mixed grasslands of $\mathrm{Ca}$ choeira do Arari. Thirteen species (33\%) were restricted to floodplain forests. In the study conducted by Ilkiu-Borges \& Lisboa (2002a), the floodplain ecosystem also showed high species richness (48 species) and the greatest number of records (416).

The areas of secondary vegetation, despite having a large number of species (20 species), had only one unique species, Microlejeunea acutifolia. A similar result was found by Ilkiu-Borges \& Lisboa (2002a). In a study conducted in municipalities of northeastern Pará, Santos \& Lisboa (2003) observed that secondary vegetation was one of the environments that presented the highest numbers of records (131) and species (35). In a subsequent study, also conducted in northeastern Pará (Santos \& Lisboa 2008), the authors again observed that secondary vegetation presented high numbers of records (336) and species richness (31), as in the present study.

The species Cheilolejeunea oncophylla, Cheilolejeunea rigidula, Lejeunea laetevirens, Calymperes afzelii, C. palisotii, C. erosum, Octoblepharum albidum, Sematophyllum subsimplex, Fissidens guianensis, Trichosteleum papillosum, Acrolejeunea emergens, Cheilolejeunea discoidea, Cololejeunea verwimpii, Frullanoides corticalis, Lopholejeunea subfusca and Microlejeunea bullata were collected in four to seven ecosystems, corresponding to $24 \%$ of the species collected and, therefore, representing the most common species in the study area.

The species Bryum coronatum, Campylopus surinamensis, Fissidens intromarginatus, Prionolejeunea denticulata, Rectolejeunea berteroana and Stictolejeunea squamata occurred only once in the area, corresponding to $9 \%$ of the species recorded in this study, and were found only in Cachoeira do Arari (Tab. 1).

Among colonization substrates of bryophytes, living tree trunks had higher representation (84\%) as it relates to number of records. This can be explained by the fact that in tropical forests it is the most available substrate, taking the form of trees, saplings, shrubs, seedlings and lianas (Gradstein 1995). Decaying tree trunks were the second most used substrate (12\%). These results corroborate those of Richards (1984), which indicated live trunks followed by decaying trunks as the substrates most used by bryophytes in tropical forests, as they are the most abundant in these types of forests. These results are also in agreement with 


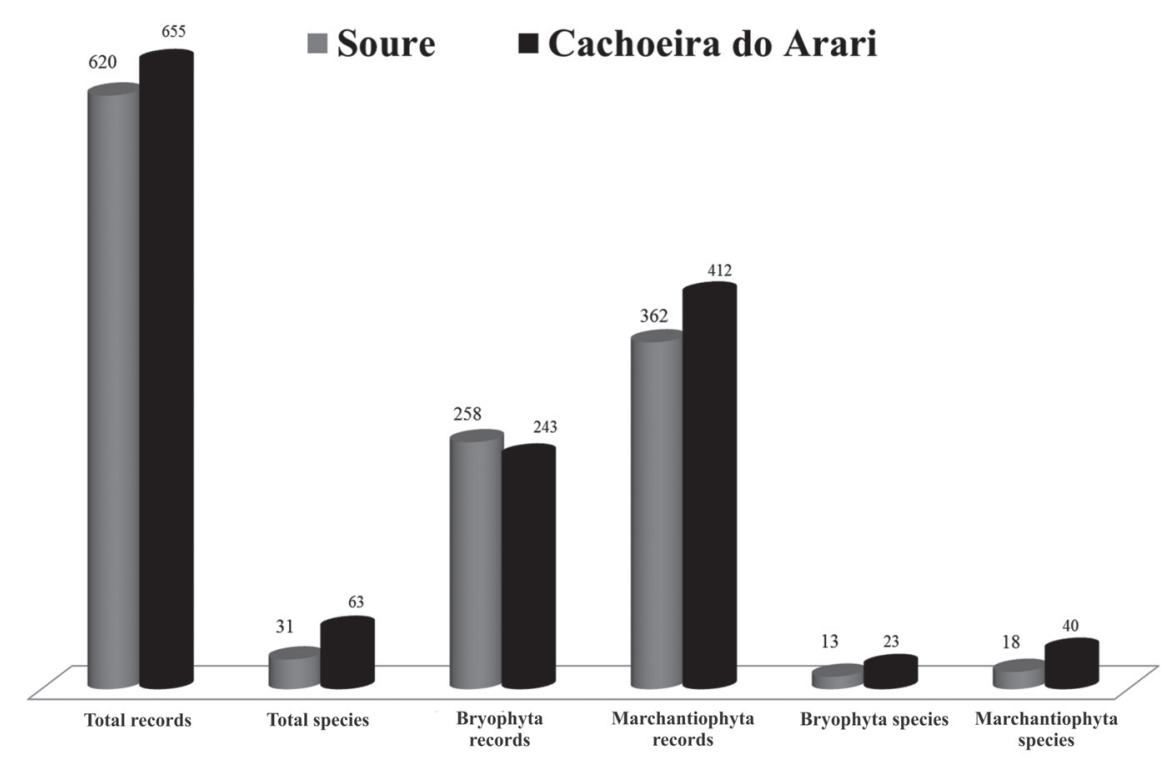

Figure 2. Number of records and of species in the municipalities of Soure and Cachoeira do Arari, Marajó Island, Brazil.

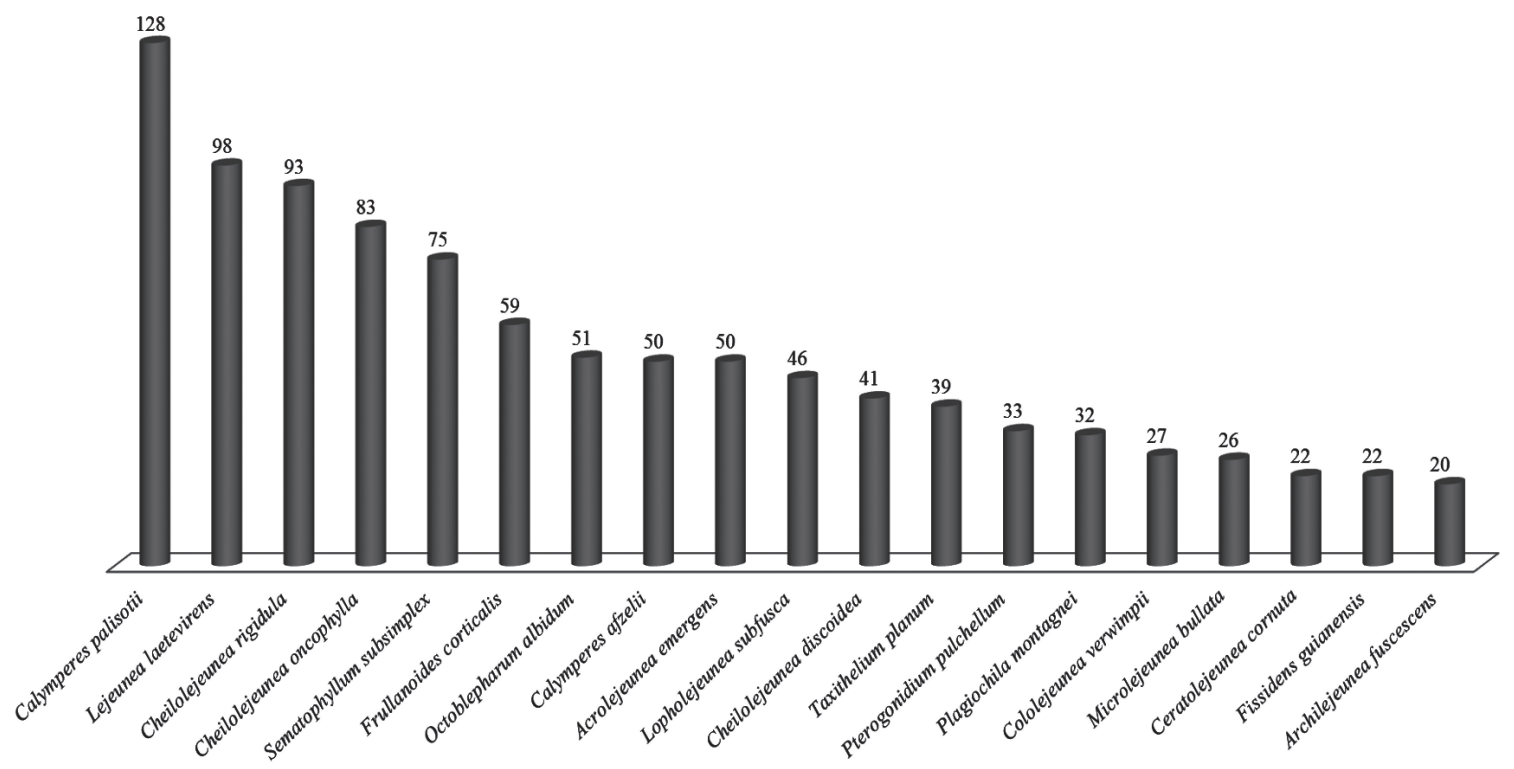

Figure 3. Species with highest number of records in the municipalities of Soure and Cachoeira do Arari, Marajó Island, Brazil.

those of other bryofloristic studies conducted in the state of Pará (Lisboa et al. 1998; 1999; Santos \& Lisboa 2008; Ilkiu-Borges et al. 2009).

Living and decaying trunks were colonized by 85 and 48 species, respectively (Fig. 4). Gradstein (1995) argues that even subtle differences in water supply, nutrients, light and inclination of the substrate affect the ability of bryophytes to establish themselves and, therefore, tree bases, trunks and ascending branches often harbor different species.
There were 20 occurrences of bryophytes on living leaves, representing five species of Lejeuneaceae. This is explained by Gradstein (1995), who stated that over 90\% of epiphyllous liverworts belong to Lejeuneaceae. Of the species encountered, Leptolejeunea elliptica, Lejeunea laetevirens and Cololejeunea verwimpii had the highest number of records, whereas Frullanoides corticalis and Archilejeunea parviflora were collected only once from this substrate. However, all of these species were collected on other types 


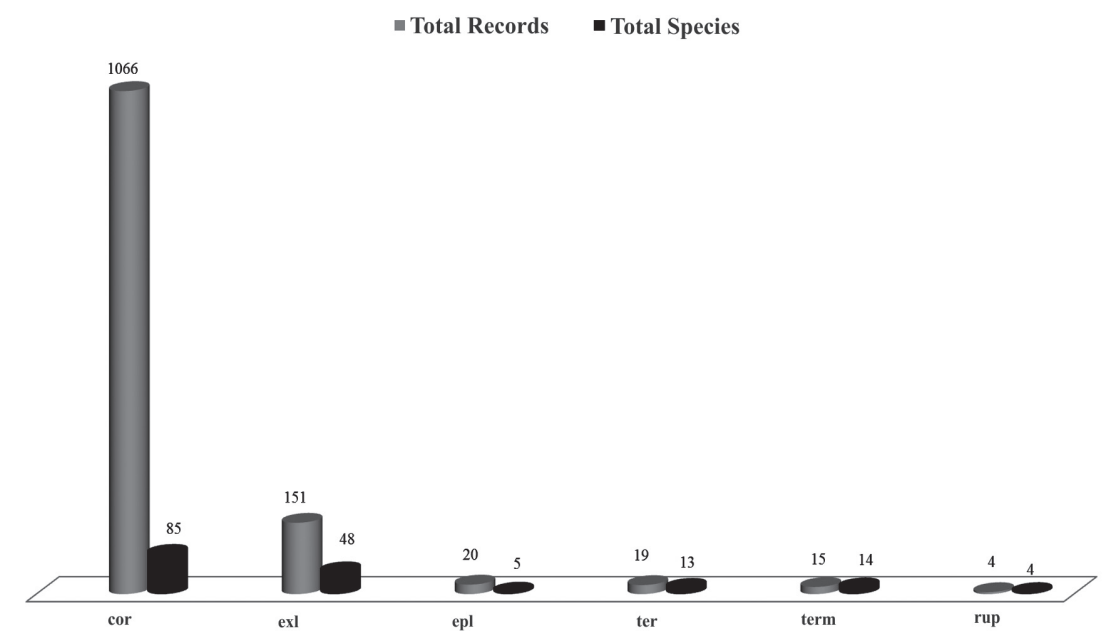

Figure 4. Total records and species by substrate in the municipalities of Soure and Cachoeira do Arari, Marajó Island, Brazil.

Table 2. Comparison of species richness across studies of bryophytes on Marajó Island, Brazil.

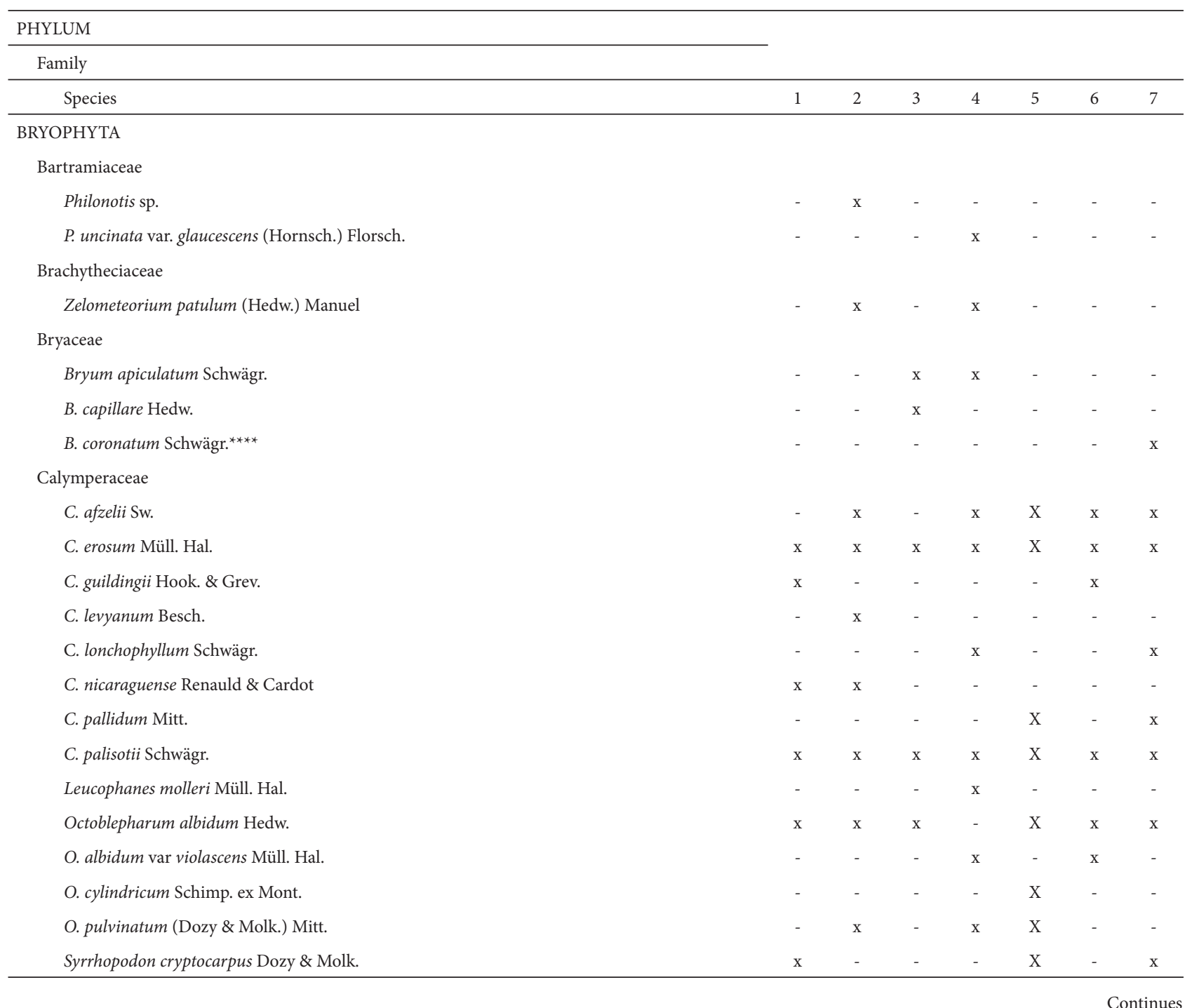


Table 2. Continuation.

\begin{tabular}{|c|c|c|c|c|c|c|c|}
\hline \multicolumn{8}{|l|}{ Family } \\
\hline Species & 1 & 2 & 3 & 4 & 5 & 6 & 7 \\
\hline S. ligulatus Mont. & $\mathrm{x}$ & - & - & - & $\mathrm{X}$ & $\mathrm{x}$ & - \\
\hline S. rigidus Hook. \& Grev. & $\mathrm{x}$ & - & - & - & & - & - \\
\hline S. incompletus Schwägr. & - & - & - & $\mathrm{x}$ & $\mathrm{X}$ & - & - \\
\hline S. incompletus Schwägr. var. incompletus & $\mathrm{x}$ & $\mathrm{x}$ & - & - & - & $\mathrm{x}$ & - \\
\hline S. incompletus Schwag var. luridus (Paris \& Broth.) Florsch. & - & $\mathrm{x}$ & - & - & - & - & - \\
\hline S. leprieurii Mont. & - & - & - & $\mathrm{x}$ & - & - & - \\
\hline \multicolumn{8}{|l|}{ Fissidentaceae } \\
\hline Fissidens elegans Brid. & - & - & - & $\mathrm{x}$ & - & - & $\mathrm{x}$ \\
\hline F. flaccidus Mitt. & - & - & - & - & - & $\mathrm{x}$ & - \\
\hline F. guianensis Mont. & - & $\mathrm{x}$ & - & - & - & - & $\mathrm{x}$ \\
\hline F. inaequalis Mitt.**** & - & - & - & - & - & - & $\mathrm{x}$ \\
\hline F. intromarginatus (Hampe) A. Jaeg. ${ }^{* * * *}$ & - & - & - & - & - & - & $\mathrm{x}$ \\
\hline F. pellucidus Hornsch. ${ }^{* * *}$ & - & - & - & - & - & - & $\mathrm{x}$ \\
\hline F. prionodes Mont. & - & $\mathrm{x}$ & $\mathrm{x}$ & - & - & - & - \\
\hline F. submarginatus Bruch ${ }^{* * * *}$ & - & - & - & - & - & - & $\mathrm{x}$ \\
\hline F. zollingeri Mont. ${ }^{* * * *}$ & - & - & - & - & - & - & $\mathrm{x}$ \\
\hline \multicolumn{8}{|l|}{ Hookeriaceae } \\
\hline Crossomitrium patrisiae (Brid.) Müll. Hal. & - & - & - & $\mathrm{x}$ & - & - & - \\
\hline \multicolumn{8}{|l|}{ Hypnaceae } \\
\hline Chryso-hypnum diminutivum (Hampe) W.R. Buck & - & - & $\mathrm{x}$ & - & - & - & - \\
\hline Ectropothecium leptochaeton (Schwägr.) W.R. Buck & - & $\mathrm{x}$ & - & - & - & - & - \\
\hline Vesicularia vesicularis (Schwägr.) Broth. & - & - & - & $\mathrm{x}$ & - & - & - \\
\hline Vesicularia vesicularis var. rutilans (Brid.) W.R. Buck & - & - & - & $\mathrm{x}$ & - & - & - \\
\hline \multicolumn{8}{|l|}{ Leucobryaceae } \\
\hline Campylopus surinamensis Müll. Hal. & - & - & - & - & $\mathrm{x}$ & - & $\mathrm{x}$ \\
\hline Leucobryum albidum (Brid. ex P. Beauv.) Lindenb. & - & - & - & $\mathrm{x}$ & - & - & - \\
\hline L. martianum (Hornsch.) Hampe ex Müll. Hal. & - & - & - & $\mathrm{x}$ & - & - & - \\
\hline \multicolumn{8}{|l|}{ Leucomiaceae } \\
\hline Leucomium strumosum (Hornsch.) Mitt. & - & - & - & $\mathrm{x}$ & - & - & - \\
\hline \multicolumn{8}{|l|}{ Neckeraceae } \\
\hline Neckeropsis undulata (Hedw.) Reichardt & - & $\mathrm{x}$ & - & $\mathrm{x}$ & - & - & - \\
\hline \multicolumn{8}{|l|}{ Orthotrichaceae } \\
\hline Groutiella tomentosa (Hornsch.) Wijk \& Margad. & - & $\mathrm{x}$ & - & - & - & - & - \\
\hline \multicolumn{8}{|l|}{ Pilotrichaceae } \\
\hline Callicostella pallida (Hornsch.) Ångström. & - & $\mathrm{x}$ & $\mathrm{x}$ & - & - & - & $\mathrm{x}$ \\
\hline Lepidopilum scabrisetum (Schwägr.) Steere. & - & - & - & $\mathrm{x}$ & - & - & - \\
\hline L. surinamense Müll. Hal. & - & $\mathrm{x}$ & - & $\mathrm{x}$ & - & - & - \\
\hline Pilotrichum bipinnatum (Schwägr.) Brid. & - & - & - & $\mathrm{x}$ & - & - & - \\
\hline P. evanescens (Müll. Hal.) Crosby & - & - & - & $\mathrm{x}$ & - & - & - \\
\hline \multicolumn{8}{|l|}{ Pottiaceae } \\
\hline Barbula agraria Hedw. & - & $\mathrm{x}$ & $\mathrm{x}$ & - & - & - & - \\
\hline Hyophila involuta (Hook.) A. Jaeg. & - & $\mathrm{x}$ & $\mathrm{x}$ & - & - & - & - \\
\hline Splachnobryum obtusum (Brid.) Müll. Hal. & - & - & - & $\mathrm{x}$ & - & - & - \\
\hline \multicolumn{8}{|l|}{ Pterobryaceae } \\
\hline Henicodium geniculatum (Mitt.) W.R. Buck & - & - & - & $\mathrm{x}$ & - & - & - \\
\hline Orthostichopsis tetragona (Sw. ex Hedw.) Broth. & - & $\mathrm{x}$ & - & - & - & - & - \\
\hline Pireella pohlii (Schwägr.) Cardot & - & $\mathrm{x}$ & - & - & - & - & - \\
\hline
\end{tabular}


Table 2. Continuation.

\begin{tabular}{|c|c|c|c|c|c|c|c|}
\hline \multicolumn{8}{|l|}{ PHYLUM } \\
\hline \multicolumn{8}{|l|}{ Family } \\
\hline Species & 1 & 2 & 3 & 4 & 5 & 6 & 7 \\
\hline \multicolumn{8}{|l|}{ Pylaisiadelphaceae } \\
\hline Isopterygium subbrevisetum (Hampe) Broth. & - & - & - & $\mathrm{x}$ & - & - & $\mathrm{x}$ \\
\hline I. tenerum (Sw.) Mitt. & - & $\mathrm{x}$ & $\mathrm{x}$ & - & - & - & $\mathrm{x}$ \\
\hline Pterogonidium pulchellum (Hook.) Müll. Hal..*** & - & - & - & - & - & - & $\mathrm{x}$ \\
\hline Taxithelium planum (Brid.) Mitt. & - & $\mathrm{x}$ & $\mathrm{x}$ & $\mathrm{x}$ & $\mathrm{x}$ & $\mathrm{x}$ & $\mathrm{x}$ \\
\hline T. pluripuctatum (Renauld \& Cardot) Broth. & - & - & $\mathrm{x}$ & - & - & - & - \\
\hline \multicolumn{8}{|l|}{ Sematophyllaceae } \\
\hline Acroporium estrellae (Müll. Hal.) Buck \& Schaf.-Verw. & - & - & $\mathrm{x}$ & - & - & - & - \\
\hline Meiothecium boryanum (Müll. Hal.) Mitt. & - & - & - & $\mathrm{x}$ & - & - & - \\
\hline M. revolubile Mitt. & - & $\mathrm{x}$ & - & - & - & - & - \\
\hline Sematophyllum adnatum (Michx.) E. G. Britton & - & $\mathrm{x}$ & - & - & - & - & - \\
\hline S. subpinnatum (Brid.) Britton & - & - & $\mathrm{x}$ & $\mathrm{x}$ & - & - & $\mathrm{x}$ \\
\hline S. subsimplex (Hedw.) Mitt. & $\mathrm{x}$ & $\mathrm{x}$ & $\mathrm{x}$ & $\mathrm{x}$ & $\mathrm{x}$ & $\mathrm{x}$ & $\mathrm{x}$ \\
\hline Sematophyllum sp. & & $\mathrm{x}$ & - & - & - & - & - \\
\hline Trichosteleum fluviale (Mitt.) Broth. & - & $\mathrm{x}$ & $\mathrm{x}$ & - & - & - & - \\
\hline T. guianae (Müll. Hal.) Broth. & - & $\mathrm{x}$ & - & - & - & - & - \\
\hline T. papillosum (Hornsch.) A. Jaeg. ${ }^{* * * *}$ & & & & & & & $\mathrm{x}$ \\
\hline T. sentosum (Sull.) A. Jaeg. & - & - & - & $\mathrm{x}$ & - & - & - \\
\hline T. subdemissum (Besch.) A. Jaeg. & $\mathrm{x}$ & - & - & - & - & $\mathrm{x}$ & $\mathrm{x}$ \\
\hline \multicolumn{8}{|l|}{ Stereophyllaceae } \\
\hline Entodontopsis leucostega (Brid.) W.R. Buck \& Ireland ${ }^{* * * *}$ & - & - & - & - & - & - & $\mathrm{x}$ \\
\hline Pilosium chlorophyllum (Hornsch.) Müll. Hal. & - & - & - & $\mathrm{x}$ & - & - & - \\
\hline Stereophyllum radicolosum (Hook.) Mitt. & - & $\mathrm{x}$ & - & - & - & - & - \\
\hline \multicolumn{8}{|l|}{ Thuidiaceae } \\
\hline Cyrto-hypnum involvens (Hedw.) W.R. Buck \& Crum & - & - & $\mathrm{x}$ & $\mathrm{x}$ & - & - & - \\
\hline C. schistostocalyx (Müll. Hal.) Buck \& Crum & - & $\mathrm{x}$ & - & - & - & - & - \\
\hline \multicolumn{8}{|l|}{ MARCHANTIOPHYTA } \\
\hline \multicolumn{8}{|l|}{ Frullaniaceae } \\
\hline Frullania apiculata (Reinw., Blume \& Nees) Dumort.*** & - & - & - & - & - & - & $\mathrm{x}$ \\
\hline F. gibbosa Nees & - & - & - & - & $\mathrm{x}$ & - & $\mathrm{x}$ \\
\hline F. riojaneirensis (Raddi) Spruce & - & - & - & - & $\mathrm{x}$ & - & - \\
\hline \multicolumn{8}{|l|}{ Lejeuneaceae } \\
\hline Acrolejeunea emergens (Mitt.) Steph. ${ }^{* * * *}$ & - & - & - & - & - & - & $\mathrm{x}$ \\
\hline A. torulosa (Lehm. \& Lindenb.) Schiffn. & - & - & - & - & - & $\mathrm{x}$ & $\mathrm{x}$ \\
\hline Archilejeunea auberiana (Mont.) A. Evans**** & - & - & - & - & - & - & $\mathrm{x}$ \\
\hline A. crispistipula (Spruce) Steph.**** & - & - & - & - & - & - & $\mathrm{x}$ \\
\hline A. fuscescens (Hampe ex Lehm.) Fulford ${ }^{* * * *}$ & - & - & - & - & - & - & $\mathrm{x}$ \\
\hline A. parviflora (Nees) Schiffn. ${ }^{* * * *}$ & - & - & - & - & - & - & $\mathrm{x}$ \\
\hline Ceratolejeunea cornuta (Lindenb.) Steph. & - & - & - & - & $\mathrm{x}$ & $\mathrm{x}$ & $\mathrm{x}$ \\
\hline C. cubensis (Mont.) Schiffn. ${ }^{* * * *}$ & - & - & - & - & - & - & $\mathrm{x}$ \\
\hline C. laetefusca (Austin) Schust. ${ }^{* * * *}$ & - & - & - & - & - & - & $\mathrm{x}$ \\
\hline C. rubiginosa Steph. & - & - & - & - & - & $\mathrm{x}$ & - \\
\hline
\end{tabular}


Table 2. Continuation.

\begin{tabular}{|c|c|c|c|c|c|c|c|c|}
\hline \multicolumn{2}{|l|}{ PHYLUM } & \multirow[b]{3}{*}{1} & \multirow[b]{3}{*}{2} & \multirow[b]{3}{*}{3} & \multirow[b]{3}{*}{4} & \multirow[b]{3}{*}{5} & \multirow[b]{3}{*}{6} & \multirow[b]{3}{*}{7} \\
\hline \multicolumn{2}{|l|}{ Family } & & & & & & & \\
\hline Species & & & & & & & & \\
\hline Cheilolejeunea adnata (Kunze) Grolle & & - & - & - & - & $\mathrm{x}$ & - & $\mathrm{x}$ \\
\hline C. comans (Spruce) Schust. ${ }^{* * * *}$ & & - & - & - & - & - & - & $\mathrm{x}$ \\
\hline C. discoidea (Lehm. \& Lindenb.) Kachr. \& Schust.**** & & - & - & - & - & - & - & $\mathrm{x}$ \\
\hline C. holostipa (Spruce) Grolle \& R.-L.Zhu ${ }^{* * *}$ & & - & - & - & - & - & - & $\mathrm{x}$ \\
\hline C. oncophylla (Ångström.) Grolle \& Reiner, M. E. & & - & - & - & - & $\mathrm{x}$ & $\mathrm{x}$ & $\mathrm{x}$ \\
\hline C. rigidula (Mont.) Schust. & & - & - & - & - & $\mathrm{x}$ & $\mathrm{x}$ & $\mathrm{x}$ \\
\hline C. trifaria (Reinw., Blume \& Nees) Mizut. & & - & - & - & - & - & $\mathrm{x}$ & - \\
\hline Cheilolejeunea sp. ${ }^{* * * *}$ & & - & - & - & - & - & - & $\mathrm{x}$ \\
\hline Cololejeunea cardiocarpa (Mont.) A. Evans & & - & - & - & - & $\mathrm{x}$ & - & $\mathrm{x}$ \\
\hline C. diaphana A. Evans $s^{* * *}$ & & - & - & - & - & - & - & $\mathrm{x}$ \\
\hline C. minutissima subsp. myriocarpa (Nees \& Mont.) Schust. ${ }^{* * *}$ & & - & - & - & - & - & - & $\mathrm{x}$ \\
\hline C. panamensis G. Dauphin \& Pócs & & - & - & - & - & - & - & $\mathrm{x}$ \\
\hline C. subcardiocarpa Tixier & & - & - & - & - & - & $\mathrm{x}$ & - \\
\hline C. verwimpii Tixier ${ }^{* *}$ & & - & - & - & - & - & - & $\mathrm{x}$ \\
\hline Frullanoides corticalis (Lehm. \& Lindenb.) Slageren & & - & - & - & - & $\mathrm{x}$ & $\mathrm{x}$ & $\mathrm{x}$ \\
\hline Lejeunea adpressa Nees*** & & - & - & - & - & - & - & $\mathrm{x}$ \\
\hline L. caulicalyx (Steph.) Reiner, M. E. \& Goda ${ }^{* * * *}$ & & - & - & - & - & - & - & $\mathrm{x}$ \\
\hline L. laetevirens Nees \& Mont. & & $\mathrm{x}$ & - & - & - & $\mathrm{x}$ & $\mathrm{x}$ & $\mathrm{x}$ \\
\hline L. phyllobola Nees \& Mont. ${ }^{* * * *}$ & & - & - & - & - & - & - & $\mathrm{x}$ \\
\hline L. trinitensis Lindenb. ${ }^{* * * *}$ & & - & - & - & - & - & - & $\mathrm{x}$ \\
\hline Leptolejeunea elliptica (Lehm. \& Lindenb.) Schiffn.**** & & - & - & - & - & - & - & $\mathrm{x}$ \\
\hline Lopholejeunea subfusca (Nees) Schiffn. & & - & - & - & - & - & $\mathrm{x}$ & $\mathrm{x}$ \\
\hline Mastigolejeunea auriculata (Wilson) Schiffn. ${ }^{* * * *}$ & & - & - & - & - & - & - & $\mathrm{x}$ \\
\hline M. innovans (Spruce) Steph. ${ }^{* *}$ & & - & - & - & - & - & - & $\mathrm{x}$ \\
\hline Microlejeunea acutifolia Steph.**** & & - & - & - & - & - & - & $\mathrm{x}$ \\
\hline M. bullata (Taylor) Steph. & & - & - & - & - & $\mathrm{x}$ & - & $\mathrm{x}$ \\
\hline M. epiphylla Bischl. & & - & - & - & - & - & $\mathrm{x}$ & $\mathrm{x}$ \\
\hline M. subulistipa Steph..* & & - & - & - & - & - & - & $\mathrm{x}$ \\
\hline Prionolejeunea denticulata (Nees) Schiffn. ${ }^{* * * *}$ & & - & - & - & - & - & - & $\mathrm{x}$ \\
\hline Rectolejeunea berteroana (Gottsche ex Steph.) A. Evans ${ }^{* * * *}$ & & - & - & - & - & - & - & $\mathrm{x}$ \\
\hline Stictolejeunea squamata (Willd. ex Weber) Schiffn. ${ }^{* * *}$ & & - & - & - & - & - & - & $\mathrm{x}$ \\
\hline Symbiezidium transversale (Sw.) Trevis. ${ }^{* * *}$ & & - & - & - & - & - & - & $\mathrm{x}$ \\
\hline \multicolumn{9}{|l|}{ Plagiochilaceae } \\
\hline \multirow[t]{2}{*}{ Plagiochila montagnei Nees ${ }^{* * * *}$} & & - & - & - & - & - & - & $\mathrm{x}$ \\
\hline & Total: 125 taxa & 12 & 32 & 18 & 34 & 23 & 23 & 67 \\
\hline
\end{tabular}

Columns: 1. - Lisboa et al. (1993); 2. - Lisboa \& Maciel (1994); 3. - Lisboa et al. (1998); 4. - Lisboa et al. (1999); 5. - Macedo (personal communication, 2009); 6. - Fagundes \& Garcia (2009 pers. comm.); 7. - this work.

${ }^{*}$ New record for South America; ${ }^{* *}$ New record for northern Brazil; ${ }^{* *}$ New record for the state of Pará; ${ }^{* * *}$ New record for Marajó Island.

of substrates and can therefore be classified as facultative epiphylls (Cornelissen \& Ter Steege 1989).

Of the 19 occurences found on the ground, there were 13 species. According to Richards (1984), terrestrial bryophytes in tropical forests are more abundant at high altitudes. Among the 15 records of bryophytes on termite mounds, there were 14 species. This type of substrate is common in studies of bryophytes in the Amazon, such as those conducted by Lisboa (1993), Ilkiu-Borges \& Lisboa (2002a), Santos \& Lisboa (2003), Souza \& Lisboa (2005), and Ilkiu-Borges et al. (2009).
Bryophytes found on rocks (rupicolous bryophytes) accounted for four records and four species. The limited number of rupicolous species is attributable to the limited availability of rocky substrate in the area.

In previous studies of the bryoflora of Marajó Island (Lisboa \& Maciel 1994; Lisboa et al. 1993, 1998, 1999) and in two more recent studies (Macedo, personal communication, 2009; Fagundes \& Garcia, personal communication, 2009), 89 species of bryophytes were recorded for this area. The present study has added 39 species ( 31 
liverworts and eight mosses) to that total (Tab. 2).. The disparity between the number of newly recorded liverwort species and that of newly recorded moss species is a consequence of the fact that many of the previous studies included only mosses.

As shown in Tab. 2, the species richness observed in the present study (67 species) was higher than in other studies conducted on Marajó Island. This might be attributable to the large sample size of the present study (617 samples collected vs. 63-122 samples collected in previous studies), as well as to the fact that we included all types of ecosystems (vs. single ecosystems in previous studies).

The species Calymperes palisotii, C. erosum and Sematophyllum subsimplex were recorded in all studies conducted on Marajó Island (Lisboa et al. 1993; Lisboa \& Maciel 1994; Lisboa et al. 1998; 1999; Macedo, personal communication, 2009; Fagundes \& Garcia, personal communication, 2009). Octoblepharum albidum, Taxithelium planum and Calymperes afzelii were collected in most of those studies. Syrrhopodon cryptocarpos was cited by Lisboa et al. (1993), by L.P. Macedo (personal communication, 2009), and in the present work. These species, in fact, are generalist species.

The present study led to the creation of 39 new records for Marajó Island. Consequently, the bryoflora in this area now accounts for $36 \%$ of the species found in the state of Pará. The great richness of the Soure and Cachoeira do Arari regions reveals the importance of the study of local flora, which create new records and thus broaden our knowledge of said flora, given that these regions harbor large numbers of species. In areas such as Marajó, which has been designated as a priority A region, or area of extreme importance for preservation (Capobianco et al. 2001), there is a need for ecosystem conservation, which will certainly slow the loss of habitat and consequently the depletion of flora.

\section{Acknowledgments}

This study received financial support in the form of a grant from the Brazilian Conselho Nacional de Desenvolvimento Científico e Tecnológico (CNPq, National Council for Scientific and Technological Development; master's scholarship grant to the first author. We thank Dr. Tamás Pocs for confirming Cololejeunea panamensis and M.Sc. Rita de Cássia Pereira dos Santos for confirming some of the moss species. We are also grateful to Dr. Marcelo Thales of the Emílio Goeldi Paraense Museum for his assistance in the creation of Fig. 1 and to the anonymous peer reviewers for their valuable contributions to improving the manuscript.

\section{References}

Alvarenga, L.D.P.; Lisboa, R.C.L. \& Tavares, A.C.C. 2007. Novas referências de hepáticas (Marchantiophyta) da Floresta Nacional de Caxiuanã para o Estado do Pará, Brasil. Acta Botanica Brasilica 21 (2): 649-656. Amaral, D.D., et al., 2007. Campos e florestas das bacias dos rios Atuá e Anajás, Ilha do Marajó. Belém. Museu Paraense Emílio Goeldi (Coleção Adolpho Ducke).

Bastos, C.J.P. 2004. Lejeuneaceae (Marchantiophyta) no Estado da Bahia, Brasil. Tese de Doutorado. São Paulo, Universidade de São Paulo.

Bischler, H.; Bonner, C.E.B. \& Müller, H.A. 1963. Studies in Lejeuneaceae VI: the genus Microlejeunea Steph. In: Central and South America. Nova Hedwigia 5(1-2): 359-411.

Brito, E.S. \& Ilkiu-Borges, A.L. 2012. Primeiro registro de Cololejeunea panamensis (Lejeuneaceae) para a América do Sul. Rodriguésia 63(3): 01-03.

Buck, W.R. 2003. Guide to the plants of Central French Guiana. Mosses part 3. Memoirs of the New York Botanical Garden.

Capobianco, J.P.R., et al., 2001. Biodiversidade na Amazônia brasileira: avaliação e ações prioritárias para a conservação, uso sustentável e repartição de benefícios. Estação Liberdade. Instituto Socioambiental, São Paulo.

Cornelissen, J.H.C. \& Ter Steege, H. 1989. Distribuition and ecology of epiphytic bryophytes and lichens in dry evergreen Forest of Guyana. Tropical Ecology 5(1): 131-150.

Costa, D.P. et al. 2007. Banco de Dados - Briófitas do estado do Rio de Janeiro. http://www.jbrj.gov.br/pesquisa/div_tax/briofitas. (Acesso em 14/01/2011).

Costa, D.P. et al. 2010. Introdução. Lista de Espécies da Flora do Brasil. http://floradobrasil.jbrj.gov.br/2010/index?mode=0\&group=Flora.Br iofitas\&family $=\&$ genus $=\&$ species $=\&$ author $=\& \operatorname{common}=\&$ region $=\&$ state $=\&$ phyto. (Acesso em 09/08/ 2010).

Crandall-Stotler, B.; Stotler, R.E. \& Long, D.G. 2009. Morphology and classification of Marchantiophyta. Pp. 1-54. In: Goffinet, B. \& Shaw, A.J. (Eds.). Bryophyte Biology. Cambridge University Press.

Cruz, M. E.M. 1987. Marajó: Essa imensidão de ilhas. São Paulo.

Dauphin, L.G. 2003. Ceratolejeunea. Flora Neotropica. Monograph 90. New York, The New York Botanical Garden.

Dauphin, G.; Pocs T.; Villarreal, J.C. \& Allen, N.S. 2006. Nuevos registros de Hepáticas y Anthocerotófitas para Panamá. Tropical Bryology 27: 73-85.

Ferreira, L.V.; Cunha, D.A. \& Ferreira, L.C.B.L. 2001. Florística, estrutura e análise de ameaça a vegetação do parque estadual do Charapucu, Ilha do Marajó, Afuá, Pará, como subsídio ao plano de manejo da Unidade de Conservação. Museu Paraense Emílio Goeldi/MCT, Relatório Técnico.

Fiaschi, P. \& Pirani, J.R. 2009. Review of plant biogeographic studies in Brazil. Journal of Systematics and Evolution 1(1):1-20.

Florschütz, R.A. 1964. The Mosses of Suriname. Musci part. I. Pp.1- 271. In: Lanjouw, J. (Ed.). Flora of Suriname. Leideman, E.J. Brill.

Florschütz-de Waard, J. 1986. Hookeriaceae: Musci II. Pp.289-350. In: Florschütz-de-Waard, J. (Ed.). Flora of Suriname. A.L. Stoffers, Lindeman.

Florschütz-de Waard, J. 1996. Sematophyllaceae. Musci III. Pp.384-438. In: Goerts-Van Rijn, A.R.A. (Ed.). Flora of the Guianas. Kew, Royal Botanical Gardens.

Florschütz-de Waard, J. \& Veling. K. 1996. Hypnaceae. Musci III. Pp.439479. In: Gorts-Van Rijn, A.R.A. (Ed.). Flora of the Guianas. Kew, Royal Botanical Gardens.

Frahm, J.P. 1991. Dricranaceae: Campylopoioidae, Paraleucobryoidae. Flora Neotropica. Monograph 54. New York, The New York Botanical Garden.

Goffinet, B.; Buck W.R. \& Shaw A.J. 2009. Morphology and classification of the Bryophyta. Pp. 55-138. In: Goffinet, B. \& Shaw, A.J. (Eds.). Bryophyte Biology. Cambridge University Press.

Gradstein, S.R. 1975. A taxonomic monograph of the genus Acrolejeunea (Hepaticae) with an arrangement of the genera of Ptychanthoideae. Bryophytorum Bibliotheca 4: 1-162.

Gradstein, S.R. 1992. The vanishing tropical rain forest as an environment for bryophytes and lichens. Pp. 232-258. In: Bates, J.W. \& Farmer, A.M. (Eds.). Bryophytes and lichens in a Changing Environment. Oxford, Claredon Press.

Gradstein, S.R. 1994. Lejeuneaceae: Ptychantheae, Brachiolejeuneae. Flora Neotropica. Monograph 62. New York, The New York Botanical Garden. 
Gradstein, S.R. 1995. Bryophyte diversity of the tropical rainforest. Archives des sciences [Société de physique et d'histoire naturelle de Genève] 48: 91-96.

Gradstein, S.R. \& Costa, D.P. 2003. The Hepaticae and Anthocerotae of Brazil. Memoirs of the New York Botanical Garden 87: 1-336.

Gradstein, R.S. \& Ilkiu-Borges, A.L. 2009. Guide to the plants of Central French Guiana. Part. 4. Liverworts and Hornworts. Memoirs of the New York Botanical Garden 76: 1-140.

Gradstein, S.R.; Churchill, S.P. \& Salazar-Allen, N. 2001. Guide to the Bryophytes of Tropical America. Memoirs of the New York Botanical Garden 86: 1-577.

Grolle, R. \& Reiner-Drehwald, M.E. 1997. Cheilolejeunea oncophylla (Ångstr.) Grolle \& Reiner comb. nov. (Lejeuneaceae), from the Neotropics. Journal of Bryology 19: 781-785.

Hallingbäck, T. \& Hodgetts, N. 2000. Mosses, Liverworts and Hornworts: Status survey and consevation action plan for Bryophytes. IUCN, Gland.

Ilkiu-Borges, A.L. 2000. Lejeuneaceae (Hepaticae) da Estação Científica Ferreira Penna, Caxiuanã, município de Melgaco, Pará. Dissertação de Mestrado. Belém, Faculdade de Ciências Agrárias do Pará.

Ilkiu-Borges, A.L. 2006. A taxonomic monograph of the genus Prionolejeunea (Lejeuneaceae, Jungermanniopsida). Göettingen, Cuvillier Verlag.

Ilkiu-Borges, A.L. et al. 2009. As Briófitas. Pp. 227-244. In: Jardim, M.A.G. (Ed.). Diversidade biológica das Áreas de Proteção Ambiental: Ilhas do Combu e Algodoal-Maiandeua. Belém, Museu Paraense Emílio Goeldi.

Ilkiu-Borges, A.L. \& Lisboa, R.C.L. 2002a. Lejeuneaceae (Hepaticae). Pp. 399-419. In: Lisboa, P.L.B. (Ed.). Caxiuanã: populações tradicionais, meio físico e diversidade biológica. Belém. Museu Paraense Emílio Goeldi.

Ilkiu-Borges, A.L. \& Lisboa, R.C.L. 2002b. Os gêneros Lejeunea e Microlejeunea (Lejeuneaceae) na Estação Científica Ferreira Penna, Estado do Pará, Brasil, e novas ocorrências. Acta Amazonica 32(4): 541-553.

Ilkiu-Borges, A.L. \& Lisboa, R.C.L. 2004a. Os gêneros Cyclolejeunea, Haplolejeunea, Harpalejeunea, Lepidolejeunea e Rectolejeunea (Lejeuneaceae, Hepaticae) na Estação Científica Ferreira Penna, Pará, Brasil. Acta Botanica Brasilica 18(3): 537-553.

Ilkiu-Borges, A.L. \& Lisboa, R.C.L. 2004b. A. Tribo Cololejeuneae (Lejeuneaceae, Hepaticae) na Estação Científica Ferreira Penna, Melgaço (PA). Acta Botanica Brasilica 18(4): 887-902.

Ilkiu-Borges, A.L.; Lisboa, R.C.L. \& Moraes, E.N.R. 2009. Avanços no conhecimento da brioflora. Pp. 313-330. In: Lisboa, P.L.B. (Ed.). Caxiuanã: Desafios para a conservação de uma Floresta Nacional na Amazônia. Belém, Museu Paraense Emílio Goeldi.

Ireland, R.R. \& Buck, W.R. 1994. Stereophyllaceae. Flora Neotropica. Monograph 65. New York, The New York Botanical Garden.

Leitão-Filho, H.F. 1987. Considerações sobre a florística de florestas tropicais e subtropicais do Brasil. Série Técnica Instituto de Pesquisas de Estudos Florestais.

Lisboa, R.C.L. 1993. Musgos Acrocárpicos do Estado de Rondônia. Belém, Museu paraense Emílio Goeldi, Colecao Adolfo Ducke.

Lisboa, R.C.L. \& Maciel, U.N. 1994. Musgos da Ilha de Marajó-I-Afuá. Boletim Museu Paraense Emílio Goeldi, Série. Botânica 10(1): 43-55.

Lisboa, R.C.L. \& Tavares, A.C.C. 2008. Briófitas de Santarém Novo, Pará. Pp. 51-61. In: Jardim, M.A.G. \& Zoghbi, M.G.B. (Eds.). A Flora Resex Chocoaré-Mato Grosso (PA): diversidades e usos. Belém, Museu Paraense Emílio Goeldi.

Lisboa, R.C.L.; Lima, M.J.L. \& Maciel, U.N. 1999. Musgos da Ilha de Marajó - II - Anajás, Pará, Brasil. Acta Amazonica 29(2): 201-206.

Lisboa, R.C.L. Muniz, A.C.M. \&. Maciel, U.N. 1998. Musgos da Ilha de Marajó - III - Chaves (Pará). Boletim Museu Paraense Emílio Goeldi, Série Botânica 14(2): 117-125

Lisboa, P.L.B.; Lisboa, R.C.L., Rosa, N.A. \& Santos, M.R. 1993. Padrões de diversidade florística na Reserva Ecológica do Bacurizal, em Salvaterra, Ilha do Marajó, Pará. Boletim Museu Paraense Emílio Goeldi, Série Botânica 9(2): 223-248.
Ministério do Meio Ambiente (MMA). 2004. http://www.mma.gov.br/ port/sca/capa/menu.html (Acesso em 08/08/ 2010).

Moraes, E.N.R. \& Lisboa, R.C.L. 2006. Musgos (Bryophyta) da Serra dos Carajás, estado do Pará, Brasil. Boletim Museu Paraense Emílio Goeldi, Série Ciências Naturais 1(1): 39-68.

Osakada, A. \& Lisboa, R.C.L. 2004. Novas ocorrências de hepáticas (marchantiophyta) Para o estado do Pará, Brasil. Acta Amazonica 34(2): 197-200

Pursell, A.R. 2007. Fissidentaceae. Flora Neotropica. Monograph 101. New York, The New York Botanical Garden.

Reese, W.D. 1993. Calymperaceae. Flora Neotropica. Monograph 58. New York, The New York Botanical Garden.

Reiner-Drehwald, M.E. 1994. Las Lejeuneaceae (Hepaticae) de Misiones, Argentina-II. Cololejeunea. Tropical Bryology 9:79-88.

Reiner-Drehwald, M.E. 1998. Las Lejeuneaceae (Hepaticae), Argentina V Cheilolejeunea y Lepidolejeunea. Tropical Bryology 14: 53-68.

Reiner-Drehwald, M.E. 2000. Las Lejeuneaceae (Hepaticae) de Misiones, Argentina VI. Lejeunea Y Taxilejeunea. Tropical Bryology 19: 81-131.

Reiner-Drehwald, M.E. 2009. Lejeunea adpressa Nees (Lejeuneaceae) a widely distributed species of tropical America. Cryptogamie, Bryo$\operatorname{logy} 30(3)$ : 329-336.

Reiner-Drehwald, M.E. \& GODA, A. 2000. Revision of the Genus Crossotolejeunea (Lejeuneaceae, Hepaticae). Journal Hattori Botanical Laboratory 89: 1-54.

Richards, P.W. 1984. The Ecology of Tropical Forest Bryophytes. Pp. 12331270. In: Schuster, R.M. (Ed.). New Manual of Bryology. Nichinan, Journal of the Hattori Botanical Laboratory.

Rizzini, C.T. 1997. Tratado de fitogeografia do Brasil. Rio de Janeiro, Âmbito Cultural Edições Ltda.

Robbins, R.G. 1952. Bryophyta ecology of a dune area in New Zealand. Vegetation, Acta Geobotanica 4: 1-131.

Santos, N.D. \& Costa, D.P. 2010. Phytogeography of the liverwort flora of the Atlantic Forest of eastern Brazil. Journal of Bryology 32: 9-22.

Santos, R.C.P. \& Lisboa, R.C.L. 2003. Musgos (Bryophyta) do Nordeste Paraense, Brasil - 1. Zona Bragantina, Microrregião do Salgado e Município de Viseu. Acta Amazonica 33(3): 415-422.

Santos, R.C. \& Lisboa, R.C.L. 2008. Musgos (Bryophyta) da Microrregião do Salgado paraense e sua utilização como possíveis indicadores de ambientes perturbados. Rodriguésia 59(2): 361-368.

Schuster, R.M. 1980. The Hepaticae and Anthocerothe of North America East of the Hundredth Meridian. New York, Columbia University Press.

Sharp, A.J.; Crum, H. \& Eckel, P.M. 1994. The Moss Flora of México Memoirs of the New York Botanical Garden 69: 1-1113

Souza, A.P.S. \& Lisboa, R.C.L. 2005. Musgos (Bryophyta) na Ilha Trambioca, Barcarena, PA, Brasil. Acta Botanica Brasilica 19(3): 487-492.

Tan, B.C. \& Pocs, T. 2000. Bryogeography and conservation of bryophytes. Pp.403-476. In: Shaw, A.J. \& Goffinet, B. (Eds): Bryophyte Biology. Cambridge University Press.

Tavares, A.C.C. 2009. Florística e Ecologia das Comunidades de Briófitas em Florestas de Terra Firme no Estado do Pará, Amazônia. Tese de Doutorado. Rio de Janeiro, Instituto de Pesquisas Jardim Botânico do Rio de Janeiro/Escola Nacional de Botânica Tropical.

Tixier, P. 1991. Bryophyta exotica-9. Quelques Lejeuneaceae (Hépatiques) nouvelles pour 1'Amérique du Sud. Candollea 46(2): 267-307.

Tropicos.org. Missouri Botanical Garden. http:/www.tropicos.org (Acesso em 20/12/2010).

Valente, E.B. \& Pôrto, K.C. 2006. Hepáticas (Marchantiophyta) de um fragmento de Mata Atlântica na Serra da Jibóia, Município de Santa Teresinha, BA, Brasil. Acta Botanica Brasilica 20(2): 433-441.

Van Slageren, M.W.S.J.M. 1985. A Taxonomic Monograph of the genera Brachiolejeunea and Frullanoides (Hepaticae), with a sem analysis of the sporophyte in the Ptychanthoideae. Mededeelingen van het Botanisch Museum en Herbarium van de Rijks Universiteit te Utrecht.

Watson, E.V. 1974. The structure and life of bryophytes. London, Hutchinson. University Library.

Yano, O. 2006. Novas adições ao catálogo de Briófitas Brasileiras. Boletim do Instituto de Botânica 17:1-142. 
Yano, O. 2008. Catálogo de Antóceros e Hepáticas Brasileiras: literatura original, basiônimo, localidade-tipo e distribuição geográfica. Boletim do Instituto de Botânica 19: 1-110.

Yano, O. \& Peralta, D.F. 2007. Briófitas da Ilha do Bom Abrigo, Estado de São Paulo, Brasil. Hoehnea 34(1): 87-94.
Yano, O. \& Peralta, D.F. 2008. Brióftas da Ilhabela, estado de São Paulo, Brasil. Hoehnea 35(1): 111-121.

Zartman, C.E. \& Ilkiu-Borges, A.L. 2007. Guide to the Epiphyllous Bryophytes of Central Amazonia. Manaus, Instituto Nacional de Pesquisa da Amazônia. 